\title{
Molecular identification of bacteria isolated from culture medium of the gold-lipped pearl oyster Pinctada maxima larvae
}

\author{
STENLY WULLUR ${ }^{1, \boldsymbol{v}}$, HATOPAN NAPITUPULU ${ }^{1}$, ELVY LIKE GINTING $^{1}$, \\ NOLDY GUSTAF FRANS MAMANGKEY ${ }^{1}$, LETHA LOUISIANAWANTANIA ${ }^{1,2}$, \\ RADOSLAV SMOLAK ${ }^{3}$, ERICK OGELLO ${ }^{4}$ \\ ${ }^{1}$ Faculty of Fisheries and Marine Science, Universitas Sam Ratulangi. Jl. Kampus, Bahu, Malalayang, Manado 95115, North Sulawesi, Indonesia \\ Tel./fax.: +62-431-868027, `email: stenlywullur@unsrat.ac.id \\ ${ }^{2}$ Ichthyology section, Zoologisches Forschungsmuseum Alexander Koenig. Adenauerallee 160, D-53113 Bonn, Germany \\ ${ }^{3}$ Department of Ecology, Faculty of Humanities and Natural Sciences, Presov University. 081 16, Presov, Slovakia \\ ${ }^{4}$ Department of Fisheries and Natural Resources, Maseno University. Kondele Kisumu-Busia Rd Maseno, Kisumu, Kenya
}

Manuscript received: 31 July 2020. Revision accepted: 20 October 2020.

\begin{abstract}
Wullur S, Napitupulu H, Wantania LL, Ginting EL, Mamangkey NGF, Smolak R, Ogello E. 2020. Molecular identification of bacteria isolated from culture medium of the gold-lipped pearl oyster Pinctada maxima larvae. Biodiversitas 21: 5291-5297. This study was conducted for the molecular identification of bacteria species isolated from culture medium of the gold-lipped pearl oyster, Pinctada maxima larvae. The pearl oysters were cultured using live-microalgae (Isochrysis sp) and fish waste diet (FWD) as food sources. Bacteria were isolated from the oyster larvae and identified based on the 16S rRNA gene sequence. The isolated bacteria were grown on agar plates and incubated at $37^{\circ} \mathrm{C}$ for 24 to 48 hours. Representative colonies of the bacteria were selected and cultured for molecular analysis. The $16 \mathrm{~S}$ rRNA genes of the bacteria were amplified and the sequences were matched with the NCBI GenBank database. Seven different colonies were observed based on morphological characters. Similarity test by conducting the Basic Local Alignment Search Tool (BLAST) in the NCBI GenBank database, using the 16S rRNA gene sequences showed that the seven isolates colonies possess high similarity to five bacteria species i.e. Pseudomonas pachastrellae, Vibrio alginolyticus, Bacillus filamentosus, Bacillus cereus and Idiomarina fontislapidosi belonging to four different genera i.e. Bacillus, Staphylococcus, Vibrio, and Alteromonas.
\end{abstract}

Keywords: 16S rRNA, bacteria, fish-waste diet, Pinctada maxima, gold-lipped pearl oyster

\section{INTRODUCTION}

Pearl oyster culture industry in Indonesia mostly uses oyster seeds collected from the wild. If not managed well, the wild harvesting can potentially destroy oyster population and may affect the sustainability of the national pearl industry (Manez et al. 2010). This is demonstrated by the Segara Anakan lagoon in South Central Java, Indonesia, where the flourishing pearl oysters Pinctada maxima/Pinctada margaritifera are depleting due to overharvesting (Manez, 2010). In order to maintain stock of oyster in the wild, several private hatcheries commenced the production of the larvae ( $P$. maxima), and the juveniles are restocked to the wild for further adult collection at suitable size prior to seeding for pearl production (Kvingedal et al. 2010).

In the process of culturing, however, hatcheries use live microalgae and are cultivated on-site as exclusive food nutrition for the larvae. In fact, the production cost of the live microalgae culture is about $30-50 \%$ of the hatchery operational cost. Also, technical sources and skilled personnel are required for successful production of live microalgae with adequate quantity and high quality. However, the unavailability of these requirements is common problem for oyster hatchery operations (Tanyaros et al. 2016; Southgate et al. 2016). For this reason, cheap and easily handed food sources based on baker's yeast were introduced. This resulted in stunted growth and high mortality of the oyster because of nutritional deficiency of the yeasts. This resulted in the growth and high mortality of oysters as there was nutritional deficiency of yeast (Tanyaros et al. 2016). Furthermore, non-living microalgae such as powder and paste were used for larval rearing of oysters (Wassnig and Southgate, 2016). The use of nonliving microalgae promotes growth and survival of reared oyster larvae, which is equivalent to live-microalgae (Southgate et al. 2016). However, individual cells of the non-living microalgal-based food are non-motile, negatively buoyant, and eventually settled onto the bottom which is the source of culture crash. Also, the powder microalgae insufficient nutrition due to drying process, while the paste product has short shelf life (Wassnig and Southgate, 2016). The prices of these two non-living microalgal-based foods are expensive, therefore they are not preferred by hatcheries in developing countries (Wullur et al. 2020). This led to the development of an inexpensive and easy diet as an alternative food for microalgae, the fish waste diet (FWD) (Ogello et al. 2018; Napitupulu et al. 2019; Ogello et al. 2019, 2020; Wullur et al. 2019, 2020). The FWD was developed from the composition of fish waste and probiotic bacteria. Attempts to feed rotifers with this diet were shown to have a high level of acceptance, as they were harvested at densities of about 2000 to 3000 ind./mL every week during semi-continuous culture 
(Ogello et al. 2018; 2019, 2020; Wullur et al. 2017, 2019). In addition, it was suspected that fish waste contains bacteria used by rotifers as their nutritional source (Wullur et al. 2020).

Pearls oysters are reported to feed on bacteria in natural environment. However, bacteria are present in the rearing water of oyster and microalgae culture in hatcheries, it provides metabolic requirements for oyster's larvae by making direct or indirect provision of organic molecules and exoenzyme required for the growth and survival of larvae (Karim et al. 2013). On the other hand, the presence of opportunistic bacteria often causes disease or massive larval mortality in oyster hatcheries (Saulnier et al. 2010). However, the use of probiotics, which provides health benefits and protection against bacterial pathogens, is essential to maintain a healthy culture environment (Karim et al. 2013). Today, the bacterial population dynamics in live cultures for $P$. maxima is not clear. Furthermore, the bacterial population identification analysis should be more important when additional diets such as FWD are used. The knowledge on bacteria present in living cultures is important for designing nutritional strategies for oyster culture. In this study, a molecular approach was used to identify the species of bacteria present in rearing water of oyster culture. Also, a small-ribosomal subunit 16S rRNA gene was sequenced to identify bacterial species.

\section{MATERIALS AND METHODS}

The larvae of pearl oyster $P$. maxima (14-days old) were cultured in $700 \mathrm{~mL}$ seawater (salinity $35 \mathrm{ppt}$ ) at a density of about 33 ind./mL for two weeks, using transparent plastic containers. Each container was equipped with aeration of $0.66 \mathrm{~mL} / \mathrm{min}$ and placed in a room at 25 $26^{\circ} \mathrm{C}$. The larvae were fed with live-microalgae Isochrysis sp. (PBM) and a FWD, which was previously soaked with EM4® (EM) for 24 hours. The preparation of the FWD was adapted as described in Patent No. P00201609066 registered in Indonesia.

The bacteria were isolated from the rearing water of oyster culture at the end of rearing period, with a sample of approximately $1 \mathrm{~mL}$ serially diluted (10 to 1000 -fold) in sterile seawater. The samples were spread on $2 \%$ nutrient agar and incubated at $37^{\circ} \mathrm{C}$ for $24-48$ hours to observe bacterial colonies. A distinct colony was further selected according to their phenotype characters and grown in nutrient broth for 24 - 48 hours to obtain pure bacterial strains. Bacteria were harvested and centrifuged at 14,000 rpm for 5 minutes for molecular analysis.

The Qiaprep Miniprep Kit (Qiagen, Hilden, Germany) was used to extract genomic DNA and 16S rRNA gene from the genomic DNA of the bacteria was amplified using two primers (8F; forward, 5' AGAGTTTGATCCTGGCTCAG-3' and 1492R; reverse 5'-ACCTTGTTACGACTT-3'). The PCR reaction was prepared with a total volume of $25 \mu \mathrm{l}$ which consist of $1 \mu \mathrm{l}$ sample, $5 \mu \mathrm{l}$ of $5 \mathrm{x}$ Hot fire pool, $1 \mu \mathrm{l}$ of each primer and 17 $\mu \mathrm{l}$ of $\mathrm{ddH}_{2} \mathrm{O}$. It was then placed in a Professional Thermocycler (Biometra, Analytik Jena) for 35 cycles amplification at $95^{\circ} \mathrm{C}$ for $6 \mathrm{~min}(1 \mathrm{cycle}), 95^{\circ} \mathrm{C}$ for $30 \mathrm{sec}$, $52^{\circ} \mathrm{C}$ for $30 \mathrm{sec}$, and $72^{\circ} \mathrm{C}$ for $30 \mathrm{sec}$ ( 34 cycles), followed by $72^{\circ} \mathrm{C}$ for $10 \mathrm{~min}$ as final cycle.

The amplicons and the primer pairs were sent to FirstBase Co., Selangor, Malaysia to sequence the 16S rRNA gene. Sequencing procedures were conducted bidirectionally using a BigDye ${ }^{\circledR}$ Terminator v.3.1 Cycles Sequencing Kit (Applied Biosystems, USA) and further read with an ABI PRISM® 377 automatic DNA sequencer. Its quality was accessed using the Sequence Scanner version 2.0 Software (Applied Biosystem). Subsequently, sequences were trimmed, assembled, and manually edited using Geneious Prime version 2020 (http://www.geneious.com, Kearse et al. 2012) prior to the application of BLAST (Basic Local Alignment Tools) analysis at The National Center for Biotechnology Information (NCBI, https://www.ncbi.nlm.nih.gov/).

\section{RESULTS AND DISCUSSION}

In this study, five species of bacteria (Pseudomonas pachastrellae, Vibrio alginolyticus, Bacillus filamentosus, Bacillus cereus, and Idiomarina fontislapidosi) were identified, belongs to 4 genera (Pseudomonas, Vibrio, Bacillus, and Idiomarina). These species obtained from rearing water of oyster larval culture were analyzed from seven isolates by conducting nucleotide BLAST using $16 \mathrm{~S}$ rRNA gene at NCBI. The percent identity of the first top nearest species of 5 isolates (Table 1) was PBM21233 (99.07\%), PBM31432 (99.64\%), EM114133 (99.21\%), EM11441 (99.01\%) and EM11442 $(98.87 \%)$, above the threshold value, while 2 isolates EM114233 (98.30\%) and EM31042 (98.58\%) were slightly below the threshold value. According to Kim et al. (2014), the threshold value to differentiate bacterial species using 16S rRNA gene has 98.65\% sequence similarity/percent identity.

Three isolates namely PBM21233, EM114233, and EM11441 collected from the two feeding treatments (PBM and EM) were identified as $P$. pachastrellae (NR 040991.1), belongs to the genus of Pseudomonas. The members of this genus inhabit a variety of environments, including terrestrial and aquatic habitats. According to Özen and Ussery (2012), the total number of species currently included in the genus Pseudomonas is around 202 species, which are important in medical or biotechnological applications. Several species such as Pseudomonas aeruginosa (Priyaja, 2012; Giri et al. 2012; Vinoj et al. 2013), Pseudomonas fluorescens (Nour and El-Ghiet, 2011; Eissa et al. 2014), Pseudomonas aestumarina, Pseudomonas synxantha, Pseudomonas chlororaphis (Sánchez et al. 2014) have reported as a potent probiotic microorganism for marine or freshwater aquaculture. In addition, $P$. aeruginosa improved the innate immunity as well as survival of carp Labeo rohita against Aeromonas hydrophila infection (Giri et al. 2012) and enhanced survival of pearl oyster Pinctada mazatlanica (Macias et al. 2010). Also, P. fluorescens reported to improve survival of rainbow trout Oncorhynchus mykiss after challenging the fish with pathogen Vibrio anguillarum, while $P$. 
aestumarina conferred protection to white shrimp Litopenaeus vannamei against vibriosis (Sánchez et al. 2014). The combination of $P$. synxantha and $P$. aeruginosa improved growth, survival and the immune responses of western king prawns Penaeus latisulcatus juveniles, while $P$. chlororaphis enhances resistance of European perch Perca fluviatilis against Aeromonas sobria infection (Sánchez et al. 2014). On the contrary, Pseudomonas plecoglossicida (Nakai, 2010), Pseudomonas gessardii (Hamza et al. 2018), Pseudomonas alcaligenes (Xu et al. 2015), Pseudomonas beatica (Lopez et al. 2012), Pseudomonas koreensis (Shahi and Mallik, 2014) and Pseudomonas putida (Mao et al. 2012) caused infection in aquaculture. Nakai (2010) and Huang et al. (2019) reported on the mass mortality of Ayu Plecoglossus altivelis and large yellow croaker Pseudosciaena crocea resulting from $P$. plecoglossicida attacks, while $P$. gessardii and $P$. alcaligenes facilitated the total mortality of freshwater crayfish Pacifastacus leniusculus (Korkut et al. 2018) and Chinese sturgeon Acipenser sinensis (Xu et al. 2015), respectively. The $P$. beatica was reported to be present in disease outbreak for flatfish Dicologlossa cuneata (Lopez et al. 2012), while P. koreensis is present in eye infections of golden mahseer Tor putitora (Shahi and Mallik, 2014). Furthermore, P. putida has been reported as an important fish pathogen of rainbow trout Oncorhynchus mykiss, European eel Anguilla anguilla, oyster toadfish Opsanus tau, and large yellow croaker Pseudosciaena crocea (Mao et al. 2012).

Table 1. Five top hits of the nearest species of the bacterial isolates after nucleotide BLAST against 16S rRNA gene in the NCBI GenBank using rRNA type strains/prokaryotic16S ribosomal RNA (bacteria and archaea) database

\begin{tabular}{|c|c|c|c|c|c|}
\hline Isolates & Nearest species (accession number) & Score & $\begin{array}{l}\text { Query } \\
\text { cover }\end{array}$ & E-value & Identity \\
\hline \multirow[t]{5}{*}{ PBM21233 } & Pseudomonas pachastrellae (NR040991.1) & 2516 & $100 \%$ & 0.0 & $99.07 \%$ \\
\hline & Pseudomonas oceani (NR152090.1) & 2516 & $100 \%$ & 0.0 & $97.79 \%$ \\
\hline & Pseudomonas aestusnigri (NR126210.1) & 2412 & $99 \%$ & 0.0 & $97.79 \%$ \\
\hline & Pseudomonas jilinensis (NR169366.1) & 2289 & $100 \%$ & 0.0 & $96.16 \%$ \\
\hline & Pseudomonas sabulinigri (NR044415.1) & 2259 & $100 \%$ & 0.0 & $95.79 \%$ \\
\hline \multirow[t]{5}{*}{ PBM31432 } & Vibrio alginolyticus (NR113781.1) & 2571 & $99 \%$ & 0.0 & $99.64 \%$ \\
\hline & Vibrio alginolyticus (NR117895.1) & 2569 & $99 \%$ & 0.0 & $99.64 \%$ \\
\hline & Vibrio alginolyticus (NR121709.1) & 2564 & $99 \%$ & 0.0 & $99.57 \%$ \\
\hline & Vibrio alginolyticus (NR118258.1) & 2564 & $99 \%$ & 0.0 & $99.57 \%$ \\
\hline & Vibrio natriegens (NR117890.1) & 2564 & $99 \%$ & 0.0 & $99.57 \%$ \\
\hline \multirow[t]{5}{*}{ EM114133 } & Bacillus filamentosus (NR134701.1) & 2521 & $98 \%$ & 0.0 & $99.21 \%$ \\
\hline & Bacillus endophyticus (NR025122.1) & 2518 & $99 \%$ & 0.0 & $98.73 \%$ \\
\hline & Bacillus shackletonii (NR025373.1) & 2224 & $99 \%$ & 0.0 & $95.00 \%$ \\
\hline & Bacillus circulans (NR112632.1) & 2211 & $99 \%$ & 0.0 & $94.92 \%$ \\
\hline & Bacillus circulans (NR104566.1) & 2207 & $99 \%$ & 0.0 & $94.98 \%$ \\
\hline \multirow[t]{5}{*}{ EM114233 } & Pseudomonas pachastrellae (NR040991.1) & 2468 & $99 \%$ & 0.0 & $98.30 \%$ \\
\hline & Pseudomonas oceani (NR152090.1) & 2362 & $99 \%$ & 0.0 & $97.02 \%$ \\
\hline & Pseudomonas aestusnigri (NR126210.1) & 2353 & $99 \%$ & 0.0 & $96.88 \%$ \\
\hline & Pseudomonas jilinensis (NR169366.1) & 2235 & $99 \%$ & 0.0 & $95.39 \%$ \\
\hline & Pseudomonas sabulinigri (NR044415.1) & 2202 & $99 \%$ & 0.0 & $95.02 \%$ \\
\hline \multirow[t]{5}{*}{ EM11441 } & Pseudomonas pachastrellae (NR040991.1) & 2527 & $100 \%$ & 0.0 & $99.01 \%$ \\
\hline & Pseudomonas oceani (NR152090.1) & 2425 & $100 \%$ & 0.0 & $99.74 \%$ \\
\hline & Pseudomonas aestusnigri (NR126210.1) & 2409 & $98 \%$ & 0.0 & $97.99 \%$ \\
\hline & Pseudomonas jilinensis (NR169366.1) & 2298 & $100 \%$ & 0.0 & $97.12 \%$ \\
\hline & Pseudomonas sabulinigri (NR044415.1) & 2266 & $99 \%$ & 0.0 & $97.81 \%$ \\
\hline \multirow[t]{5}{*}{ EM11442 } & Bacillus cereus (NR115526.1) & 2516 & $100 \%$ & 0.0 & $98.87 \%$ \\
\hline & Bacillus proteolyticus (NR157735.1) & 2516 & $100 \%$ & 0.0 & $98.87 \%$ \\
\hline & Bacillus wiedmannii (NR152692.1) & 2516 & $100 \%$ & 0.0 & $98.87 \%$ \\
\hline & Bacillus cereus (NR114582.1) & 2516 & $100 \%$ & 0.0 & $98.87 \%$ \\
\hline & Bacillus cereus (NR115714.1) & 2516 & $100 \%$ & 0.0 & $98.87 \%$ \\
\hline \multirow[t]{5}{*}{ EM31042 } & Idiomarina fontislapidosi (NR029115.1) & 2481 & $99 \%$ & 0.0 & $98.58 \%$ \\
\hline & Idiomarina baltica (NR027560.1) & 2442 & $99 \%$ & 0.0 & $98.08 \%$ \\
\hline & Idiomarina aquatica (NR144584.1) & 2364 & $99 \%$ & 0.0 & $97.09 \%$ \\
\hline & Idiomarina seosinensis (NR025826.1) & 2263 & $98 \%$ & 0.0 & $96.57 \%$ \\
\hline & Idiomarina abyssalis (NR024891.1) & 2254 & $99 \%$ & 0.0 & $95.66 \%$ \\
\hline
\end{tabular}


So far there are no reports about the role of $P$. pachastrellae in aquaculture. It was first isolated from marine sponge specimen and assigned as a new species in 2005 (Kennedy et al. 2014). P. pachastrellae was further identified in the polluted sand samples after a marine oil spill (Lamendella et al. 2014), as well as deep seawater (depth of $1390 \mathrm{~m}$ ) (Wang and Sun, 2016), and also in soil samples collected from an oily environment in close proximity to the seashore (Kaskatepe et al. 2017). Apart from having highest sequences identities with $P$. pachastrellae, the isolates PBM21233, EM114233 and EM11441 share high sequences identities with Pseudomonas oceani (97.79, 97.02, and 99.74\% identities, respectively (Table 1)). Wang et al. (2020) placed the two closes relate Pseudomonas species in the group of Pseudomonas pertucinogena lineage. The P. oceani inhabiting deep seawaters (Wang and Sun, 2016) and oily polluted environment ( $\mathrm{Li}$ et al. 2020) which is similar with $P$. pachastrellae. This study showed for the first time the presence of $P$. pachastrellae in the rearing water of the gold-lipped pearl $P$. maxima larvae which was found in both PBM and EM treatments.

Isolate PBM31432 collected from PBM treatment showed percent identity value above the threshold which referred to Vibrio alginolyticus (NR113781.1), a species of genus Vibrio. The species in this genus inhabit the aquatic environment. They are judged to be responsible for vibriosis, implicated in economic losses to the aquaculture industry, and is also frequently associated with diseasecausing microorganism in humans (Ashrafudoulla et al. 2020). In addition, V. alginolyticus is implicated in severe soft tissue infections, sepsis, and other extraintestinal infections in human, through water exposure or the consumption of contaminated seafood (Slifka et al. 2017). This species together with Vibrio parahaemolyticus, Vibrio harveyi, Vibrio owensii and Vibrio campbelli were predominantly associated as a causative agent of vibriosis on farmed aquatic animals (Ina et al. 2019). Specifically, $V$. alginolyticus were more frequently reported in the prevalence of many farmed fish species including olive flounder Paralichthys olivaceus, black rockfish Sebastes schlegeli, red sea bream Pagrus major, and sea bass Lateolabrax japonicus, kelp grouper Epinephelus bruneus, Orange-spotted grouper Epinephelus coioides (Oh et al. 2011; Harikrishnan et al. 2012; Wang et al. 2014). The $V$. alginolyticus was also reported in the infection of farmed shrimp (i.e. white shrimp Litopenaeus vannamei, shrimp Marsupenaeus japonicus (Kitikew et al. 2013; Zhu et al. 2016), abalone (i.e. small abalone Haliotis diversicolor, red abalone Haliotis rufescens (Wu et al. 2011) and farmed pearl oyster (i.e. Akoya pearl oyster Pinctada fucata, Pinctada martensii, Pinctada maxima (Wang et al. 2012; 2016; Adzigbli et al. 2020)). The $V$. alginolyticus in this study was only identified in PBM and not in EM treatments. Based on the consideration as a pathogen in the competitive processes, this species is suggests to be possibly displaced by beneficial bacteria in EM.

Two isolates, EM114133 and EM11442, which were collected from EM feeding treatment showed percent identity value above threshold referring to species of Bacillus filamentosus (NR134701.1) and Bacillus cereus (NR 115526.1) respectively. Species of bacteria in this genus are often referred to as probiotic microorganisms, as they provide health benefits to the host. According to Cutting (2011), genus Bacillus was used for decades as probiotic medicine or dietary supplements for human or veterinary use. In aquaculture, they play an important role in modulating hepatic indexes, gene expression, antioxidant and digestive enzymes. They also enhance water quality, disease resistance and immunity to promote better growth and survival of the reared fish or larvae (Kuebutornye et al. 2019). Particularly, B. cereus has generally been recognized as a human pathogen due to their role in food poisoning. In aquaculture, however, B. cereus has a significant role in enhancing immune responses, growth, or disease resistance to cultured fish (i.e. rainbow trout Oncorhynchus mykiss, silver catfish Rhamdia quelen, catfish Clarias gariepinus, Asian sea bass Lates calcarifer, Crucian Carp Carassius auratus gibelio, tambaqui Colossoma macropomum, Pengze crucian carp Carassius auratus var. Pengze, grouper Epinephelus lanceolatus and Epinephelus fuscoguttatus (Orsod et al. 2012; Souza et al. 2012; Gisbert et al. 2013; Hapsari, 2016; He et al. 2017; Jiang et al. 2019; Yang et al. 2019), cultured shrimp (i.e. giant tiger prawn Penaeus monodon, pacific white shrimp Litopenaeus vannamei, pink shrimp Farfantepenaeus brasiliensis, whiteleg shrimp Penaeus vannamei (De Souza et al. 2012; Chandran et al. 2014; Hao et al. 2014; Khademzade et al. 2020)), and other aquatic organisms (i.e. sea cucumber Apostichopus japonicus, hooded oyster Saccostrea cucullata, mud crab Scylla paramamosain (Umayaparvathi et al. 2013; Wu et al. 2014 Zhao et al. 2016). However, there have been no reports of the presence of B. filamentosus in aquaculture. It was first isolated from a marine sediment in India and was assigned as a new species in 2015 (Sonalkar et al. 2015). Further, the $B$. filamentosus was reported as a plant growth promoting bacteria on wheat Triticum aestivum grown in a saline environment (Khalifa et al. 2020). Interestingly, two species of Bacillus i.e. B. cereus and B. filamentosus in this study were only found in EM treatment, which shows an opportunity for using probiotic supplements to supply good bacteria as probiotics in oyster larvae culture.

Isolate EM31042 from EM feeding treatment showed percent identity value lower than the threshold referring to species Idiomarina fontislapidosi (NR 029115.1), belongs to the genus Idiomarina. This genus is a member of the family Idiomarinaceae proposed by Innova et al.(2000), to accommodate true marine bacterial species in the group of Alteromonas-like $\gamma$-Proteobacteria. The genus Idiomarina currently consists of about 27 species and are typically euryhalophiles thriving in wide salinity ranges of marine environment (Liu et al. 2018). These include coastal and oceanic waters and sediments (Zhang et al. 2012; Hameed et al. 2016), saline-alkaline soil (Leon et al. 2015), inland hypersaline wetlands (Zhong et al. 2014), solar salt-making works (Lee et al. 2015) and deep sea sediment (Du et al. 2015). In aquaculture, bacteria in this genus live in a 
recirculating aquaculture system with other heterotrophic bacteria (Michaud et al. 2009; Garcia et al. 2019; Teitge et al. 2020). They are also found as microbiome in fish gut (Yukgehnaish et al. 2020), in brine shrimp Artemia franciscana (Riddle et al. 2013), in a microalgal mass culture for finfish hatchery (Sandhya et al. 2017). However, their role in aquaculture, whether as a pathogen or probiotic is not well known.

In conclusion, this study shows that the rearing water of oyster larval culture contains at least 5 different species of bacteria, which are $P$. pachastrellae (PBM21233, EM114233, and EM11441), V. alginolyticus (PBM31432), B. filamentosus (EM114133), B. cereus (EM11442) and I. fontislapidosi (EM31042) belonging to the genus of Pseudomonas, Vibrio, Bacilus and Idiomarina. The species of bacteria in the treatment of PBM were P. pachastrellae and $V$. alginolyticus, while those in the treatment of EM were $P$. pachastrellae, B. filamentosus, B. cereus and $I$. fontislapidosi. In addition, EM treatment is suspected to involve bacterial species in the process of diet decomposition and subsequently became a food source or decomposed organic material as nutrition for the oyster larvae

\section{ACKNOWLEDGEMENTS}

The authors are grateful to the Indonesian Ministry of Research and Technology (Kemenristek)/National Agency for Research and Innovation (BRIN) Indonesia and Sam Ratulangi University, Manado, Indonesia for funding this study, and also to the pearl oyster hatchery, PT. Arta Samudera Bitung, for providing the pearl oyster larvae.

\section{REFERENCES}

Adzigbli L, Hao R, Jiao Y, Deng Y, Du X, Wang Q, Huang R. 2020. Immune response of pearl oysters to stress and diseases. Rev Aquacult 12: 513-523.

Ashrafudoulla M, Mizan MFR, Park SH, Ha SD. 2020. Current and future perspectives for controlling Vibrio biofilms in the seafood industry: a comprehensive review. Crit Rev Food Sci Nutr. DOI: 10.1080/10408398.2020.1767031

Cutting SM. 2011. Bacillus probiotics. Food Microbiol 28: 214-220.

De Souza DM, Suita SM, Leite FPL, Romano LA, Wasielesk W, Ballester ELC. 2012. The use of probiotics during the nursery rearing of the pink shrimp Farfantepenaeus brasiliensis (Latreille, 1817) in a zero exchange system. Aquacult Res 43 (12): 1828-1837.

Dias JA, Abe HA, Sousa NC, Couto MV, Cordeiro CA, Meneses JO et al. 2018. Dietary supplementation with autochthonous Bacillus cereus improves growth performance and survival in tambaqui Colossoma macropomum. Aquaculture Research 49: 3063-3070.

Du J, Lai Q, Liu Y, Du Y, Liu X, Sun F, Shao Z. 2015. Idiomarina atlantica sp. nov., a marine bacterium isolated from the deep sea sediment of the North Atlantic Ocean. Antonie Van Leeuwenhoek 107: 393-401.

Eissa N, Abou El-Gheit N, Shaheen AA. 2014. Protective effect of Pseudomonas fluorescens as a probiotic in controlling fish pathogens. Am J Biosci 2: 175-181.

Garcia MME, Cáceres J, Vásquez R, Cruz, R. 2019. Bacteriological water quality of recirculating aquatic systems for maintenance of yellowtail amberjack Seriola lalandi. J World Aquacult Soc 50: 934-953.

Giri SS, Sen SS, Sukumaran V. 2012. Effects of dietary supplementation of potential probiotic Pseudomonas aeruginosa VSG-2 on the innate immunity and disease resistance of tropical freshwater fish, Labeo rohita. Fish Shellfish Immunol 32: 1135-1140.

Gisbert E, Castillo M, Skalli A, Andree KB, Badiola I. 2013. Bacillus cereus var. toyoi promotes growth, affects the histological organization and microbiota of the intestinal mucosa in rainbow trout fingerlings. J Anim Sci 91: 2766-2774.

Hameed A, Lin SY, Lai WA, Shahina M, Liu YC, Hsu YH, Young CC. 2016. Idiomarina tyrosinivorans sp. nov., isolated from estuarine surface water. Intl J Syst Evol Microbiol 66: 5384-5391.

Hamza F, Kumar AR, Zinjarde S. 2018. Efficacy of cell free supernatant from Bacillus licheniformis in protecting Artemia salina against Vibrio alginolyticus and Pseudomonas gessardii. Microb Pathogen 116: 335-344.

Hao K, Liu JY, Ling F, Liu XL, Lu L, Xia L, Wang GX. 2014. Effects of dietary administration of Shewanella haliotis D4, Bacillus cereus D7 and Aeromonas bivalvium D15, single or combined, on the growth, innate immunity and disease resistance of shrimp, Litopenaeus vannamei. Aquaculture 428: 141-149.

Hapsari F. 2016. The effect of fermented and non-fermented biofloc inoculated with bacterium Bacillus cereus for catfish (Clarias gariepinus) juveniles. Aquacult Aquar Conserv Legisl 9: 334-339.

Harikrishnan R, Kim JS, Balasundaram C, Heo MS. 2012. Immunomodulatory effects of chitin and chitosan enriched diets in Epinephelus bruneus against Vibrio alginolyticus infection. Aquaculture 326: 46-52.

Huang L, Zuo Y, Jiang Q, Su Y, Qin Y, Xu X, et al. 2019. A metabolomic investigation into the temperature-dependent virulence of Pseudomonas plecoglossicida from large yellow croaker (Pseudosciaena crocea). J Fish Dis 42: 431-446.

Ina SMY, Alsaari N, Mohamad A, Mursidi FA, MohdAris A, Amal MNA, eta al. 2019. Vibriosis in fish: a review on disease development and prevention. J Aquat Anim Health 31: 3-22.

Jiang Y, Zhou S, Chu W. 2019. The effects of dietary Bacillus cereus QSI-1 on skin mucus proteins profile and immune response in Crucian Carp (Carassius auratus gibelio). Fish Shellfish Immunol 89, 319-325.

Karim M, Zhao W, Rowley D, Nelson D, Gomez CM. 2013. Probiotic strains for shellfish aquaculture: protection of eastern oyster, Crassostrea virginica, larvae and juveniles against bacterial challenge. J Shellfish Res 32: 401-408.

Kaskatepe B, Yildiz S, Gumustas M, Ozkan S. 2017. Rhamnolipid production by Pseudomonas putida IBS036 and Pseudomonas pachastrellae LOS20 with using pulps. Curr Pharm Anal 13: 138144.

Kennedy J, Flemer B, Jackson SA, Morrissey JP, O'Gara F, Dobson AD. 2014. Evidence of a putative deep-sea specific microbiome in marine sponges. PLoS One 9: e91092. DOI: 10.1371/journal.pone.0091092.

Khademzade O, Zakeri M, Haghi M, Mousavi SM. 2020. The effects of water additive Bacillus cereus and Pediococcus acidilactici on water quality, growth performances, economic benefits, immunohematology and bacterial flora of whiteleg shrimp Penaeus vannamei Boone, 1931) reared in earthen ponds. Aquacult Res 51: 1759-1770.

Khalifa AY, Metwally A, Ammar RB, Farghaly FA. 2020. ACC Deaminase-Containing Rhizobacteria from Rhizosphere of Zygophyllum coccineum Alleviate Salt Stress Impact on Wheat (Triticum aestivum L.). Sci J King Faisal Univ Basic Appl Sci 21: 89-102.

Kim M, Oh HS, Park SC, Chun J. 2014. Towards a taxonomic coherence between average nucleotide identity and $16 \mathrm{~S}$ rRNA gene sequence similarity for species demarcation of prokaryotes. Intl J Syst Evol Microbiol 64: 346-351.

Kitikiew S, Chen JC, Putra DF, Lin YC, Yeh ST, Liou CH. 2013. Fucoidan effectively provokes the innate immunity of white shrimp Litopenaeus vannamei and its resistance against experimental Vibrio alginolyticus infection. Fish Shellfish Immunol 34: 280-290.

Korkea ATL, Heikkinen J, Thompson KD, Von Wright A, Austin B. 2011. Pseudomonas sp. M174 inhibits the fish pathogen Flavobacterium psychrophilum. J Applied Microbiol 111:266-277.

Korkut GG, Söderhäll I, Söderhäll K, Noonin C. 2018. The effect of temperature on bacteria-host interactions in the freshwater crayfish, Pacifastacus leniusculus. J Invert Pathol 157: 67-73.

Kuebutornye FK, Abarike ED, Lu Y. 2019. A review on the application of Bacillus as probiotics in aquaculture. Fish Shellfish Immunol 87: 820828.

Kvingedal R, Evans BS, Lind CE, Taylor JJ, Dupont NM, Jerry DR. 2010. Population and family growth response to different rearing location, 
heritability estimates and genotypexenvironment interaction in the silver-lip pearl oyster (Pinctada maxima). Aquaculture 304: 1-6.

Lamendella R, Strutt S, Borglin S, Chakraborty R, Tas N, Mason OU, Hultman J, Prestat E, Hazen TC, Jansson JK. 2014. Assessment of the Deepwater Horizon oil spill impact on Gulf Coast microbial communities. Front Microbiol 5: 130.

Lee JC, Kim YS, Yun BS, Whang KS. 2015. Idiomarina halophila sp. nov., isolated from a solar saltern sediment. Intl J Syst Evol Microbiol 65: $1268-1273$

León MJ, Martínez-Checa F, Ventosa A, Sánchez-Porro C. 2015 Idiomarina aquatica sp. nov., a moderately halophilic bacterium isolated from salterns. Intl J Syst Evol Microbiol 65: 4595-4600.

Li J, Wang LH, Xiang FG, Ding WL, Xi LJ, Wang MQ, et al. 2020. Pseudomonas phragmitis sp. nov., isolated from petroleum polluted river sediment. Intl J Syst Evol Microbiol 70: 364-372.

Liu Y, Lai Q, Shao Z. 2018. Genome-based analysis reveals the taxonomy and diversity of the family Idiomarinaceae. Front Microbiol 9: 2453. DOI: $10.3389 /$ fmicb.2018.02453.

López JR, Diéguez AL, Doce A, De la Roca E, De la Herran R, Navas JI, et al. 2012. Pseudomonas baetica sp. nov., a fish pathogen isolated from wedge sole, Dicologlossa cuneata (Moreau). Intl J Syst Evol Microbiol 62: 874-882

Macias AOL, Ramirez OJJ, Cordova CAI, Saucedo PE. 2010. Evaluation of natural and commercial probiotics for improving growth and survival of the pearl oyster, Pinctada mazatlanica, during late hatchery and early field culturing. J World Aquac Soc 41: 447-454

Manez KS. 2010. Java's forgotten pearls: the history and disappearance of pearl fishing in the Segara Anakan lagoon, South Java, Indonesia. J Histor Geogr 36: 367-376.

Mao Z, Qiu Y, Zheng L, Chen J, Yang J. 2012. Development of a visual loop-mediated isothermal amplification method for rapid detection of the bacterial pathogen Pseudomonas putida of the large yellow croaker (Pseudosciaena crocea). J Microbiol Methods 89: 179-184.

Michaud L, Lo Giudice A, Troussellier M, Smedile F, Bruni V, Blancheton JP. 2009. Phylogenetic characterization of the heterotrophic bacterial communities inhabiting a marine recirculating aquaculture system. J Appl Microbiol 107: 1935-1946.

Nakai T. 2010. Application of bacteriophages for control of infectious diseases in aquaculture. In: Parviz M, Sabour MW (eds). Bacteriophages in the Control of Food-and Waterborne Pathogens American Society of Microbiology, Washington, DC.

Napitupulu HG, Rumengan IF, Wullur S, Ginting EL, Rimper JR, Toloh BH. 2019. Bacillus sp. as a decomposition agent in the culture of Brachionus rotundiformis using raw fish as a source of nutrition. Jurnal Ilmiah Platax 7 (1): 158-169. [Indonesian].

Nour E, ElGhiet ENA. 2011. Efficacy of pseudomonas fluorescens as biological control agent against Aeromonas hydrophila infection in Oreo chromisniloticus. World J Fish Marine Sci 3: 564-569.

Ogello EO, Wullur S, Hagiwara A. 2019. Blending fishwastes and chicken manure extract as low-cost and stable diet for mass culture of freshwater zooplankton, optimized for aquaculture. IOP Conf Ser Mater Sci Eng 567 (1): 012022. DOI: 10.1088/1757899X/567/1/012022

Ogello EO, Wullur S, Sakakura Y, Hagiwara A. 2018. Composting fishwastes as low-cost and stable diet for culturing Brachionus rotundiformis Tschugunoff (Rotifera): Influence on water quality and microbiota. Aquaculture 486: 232-239.

Ogello EO, Wullur S, Yoshitaka S, Hagiwara A. 2020. Dietary value of waste-fed rotifer Brachionus rotundiformis on the larval rearing of Japanese whiting Sillago japonica. E3S Web of Conferences. DOI: 10.1051/e3sconf/202014701005

Oh EG, Son KT, Yu H, Lee TS, Lee HJ, Shin S, et al. 2011. Antimicrobial resistance of Vibrio parahaemolyticus and Vibrio alginolyticus strains isolated from farmed fish in Korea from 2005 through 2007. J Food Prot 74: 380-386

Orsod M, Joseph M, Huyop F. 2012. Characterization of exopolysaccharides produced by Bacillus cereus and Brachybacterium sp. isolated from Asian sea bass (Lates calcarifer). Mal J Microbiol 8: 170-174.

Özen AI, Ussery DW. 2012. Defining the Pseudomonas genus: where do we draw the line with Azotobacter?. Microbial Ecol 63: 239-248.

Preetha R, Vijayan KK, Jayapraksh NS, Alavandi SV, Santiago TC, Singh IB. 2015. Optimization of culture conditions for mass production of the probiotics Pseudomonas MCCB 102 and 103 antagonistic to pathogenic Vibrios in aquaculture. Probiotics Antimicrob Proteins 7: $137-145$
Priyaja P. 2012. Pyocyanin (5-methyl-1-hydroxyphenazine) produced by Pseudomonas aeruginosa as antagonist to vibrios in aquaculture: over expression, downstream process and toxicity. [Dissertation]. Cochin University of Science and Technology, India.

Richards GP, Watson MA, Needleman DS, Church KM, Häse CC. 2015. Mortalities of Eastern and Pacific oyster larvae caused by the pathogens Vibrio coralliilyticus and Vibrio tubiashii. Appl Environ Microbiol 81: 292-297.

Riddle MR, Baxter BK, Avery BJ. 2013. Molecular identification of microorganisms associated with the brine shrimp Artemia franciscana. Aquat Biosyst 9: 7. DOI: 10.1186/2046-9063-9-7.

Sánchez PT, Zarzuela RI, de Blas I, Balcázar JL. 2014. Probiotics in aquaculture: a current assessment. Rev Aquacult 6: 133-146.

Sandhya SV, Preetha K, Vijayan KK. 2017. Phylogenetic diversity of culturable bacteria in Chaetoceros gracilis mass culture system of a marine finfish hatchery. J Mar Biol Assoc India 59:12-18.

Saulnier D, De Decker S, Haffner P, Cobret L, Robert M, Garcia C. 2010. A large-scale epidemiological study to identify bacteria pathogenic to Pacific oyster Crassostrea gigas and correlation between virulence and metalloprotease-like activity. Microb Ecol 59: 787-798.

Shahi N, Mallik SK. 2014. Recovery of Pseudomonas koreensis from eye lesions in golden mahseer, Tor putitora (Hamilton, 1822) in Uttarakhand, India. J Fish Dis 37: 497-500.

Sitdhipol J, Visessanguan W, Benjakul S, Yukphan P, Tanasupawat S. 2013. Idiomarina piscisalsi sp. nov., from fermented fish (pla-ra) in Thailand. J Gen Appl Microbiol 59: 385-391.

Slifka KJ, Newton AE, Mahon BE. 2017. Vibrio alginolyticus infections in the USA, 1988-2012. Epidemiol \& Infection, 145: 1491-1499.

Sonalkar VV, Mawlankar R, Ramana VV, Joseph N, Shouche YS, Dastager SG. 2015. Bacillus filamentosus sp. nov., isolated from sediment sample. Antonie van Leeuwenhoek 107: 433-441.

Southgate PC, Beer AC, Ngaluafe P. 2016. Hatchery culture of the winged pearl oyster, Pteria penguin, without living microalgae. Aquaculture 451: $121-124$

Souza DMD, Martins GB, Piedras SRN, Pouey JLOF, Robaldo RB, Leite FPL. 2012. Probiotic actions of Bacillus cereus var. toyoi and Saccharomyces boulardii in silver catfish (Rhamdia quelen) larvae culture. Revista Brasileira de Zootecnia 41 (3): 815-819.

Tanyaros S, Sujarit C, Jansri N, Tarangkoon W. 2016. Baker's yeast as a substitute for microalgae in the hatchery rearing of larval and juvenile tropical oyster (Crassostrea belcheri, Sowerby 1871). J Appl Aquacult 28: 35-46

Teitge F, Peppler C, Steinhagen D, Jung SV. 2020. Effect of disinfection with peracetic acid on the microbial community of a seawater aquaculture recirculation system for Pacific white shrimp (Litopenaeus vannamei). J Fish Dis 43: 991-1017.

Umayaparvathi S, Meenakshi S, Arumugam M, Balasubramanian T. 2013. Purification and characterization of protease from Bacillus cereus SU12 isolated from oyster Saccostrea cucullata. Afr J Biotechnol 12:40.

Vinoj G, Vaseeharan B, DavidJayaseelan B, Rajakumaran P, Ravi C. 2013. Inhibitory effects of Bacillus licheniformis (DAB1) and Pseudomonas aeruginosa (DAP1) against Vibrio parahaemolyticus isolated from Fenneropenaeus indicus. Aquacult Intl 21: 1121-1135.

Wang JW, Cai M, Nie Y, Hu B, Yang Y, Wu XL. 2020. Pseudomonas jilinensis sp. nov., isolated from oil production water of Jilin oilfield in China. Curr Microbiol. DOI: 10.1007/s00284-019-01798-2.

Wang MQ, Sun L. 2016. Pseudomonas oceani sp. nov., isolated from deep seawater. Intl J Syst Evol Microbiol 66: 4250-4255.

Wang Y, Fu D, Luo P, He X. 2012. Identification of the immune expressed sequence tags of pearl oyster (Pinctada martensii, Dunker 1850) responding to Vibrio alginolyticus challenge by suppression subtractive hybridization. Compar Biochem Physiol Part D: Genom Proteom 7: 243-247.

Wang YD, Huang SJ, Chou HN, Liao WL, Gong HY, Chen JY. 2014. Transcriptome analysis of the effect of Vibrio alginolyticus infection on the innate immunity-related complement pathway in Epinephelus coioides. BMC Genomics 15: 1102. DOI: 10.1186/1471-2164-151102

Wang Z, Wang B, Chen G, Jian J, Lu Y, Xu Y, Wu Z. 2016. Transcriptome analysis of the pearl oyster (Pinctada fucata) hemocytes in response to Vibrio alginolyticus infection. Gene 575: 421-428.

Wassnig M, Southgate PC. 2016. The effects of stocking density and ration on survival and growth of winged pearl oyster (Pteria penguin) 
larvae fed commercially available microalgae concentrates. Aquacult Rep 4: 17-21.

Wu CJ, Wang H, Chan YL, Li TL. 2011. Passive immune-protection of small abalone against Vibrio alginolyticus infection by anti-Vibrio IgY-encapsulated feed. Fish Shellfish Immunol 30: 1042-1048.

Wu HJ, Sun LB, Li CB, Li ZZ, Zhang Z, Wen XB, et al. 2014 Enhancement of the immune response and protection against Vibrio parahaemolyticus by indigenous probiotic Bacillus strains in mud crab (Scylla paramamosain). Fish Shellfish Immunol 41: 156-162.

Wullur S, Ginting EL, Waraow V, Rumengan IFM, Ogello EO, Hagiwara A. 2019. Growth response of rotifers on a bacterial-based diet made from fishwastes. IOP Conf Ser: Mater Sci Eng 567: 012030. DOI: 10.1088/1757-899X/567/1/012030.

Wullur S, Napitupulu H, Wantania LL, Ginting EL, Warouw V, Tilaar S, Rumengan IFM. 2020. Molecular identification of bacteria isolated from culture medium of rotifer fed on fishery waste diet. Biodiversitas 21: 2735-2740.

Xu J, Zeng X, Jiang N, Zhou Y, Zeng L. 2015. Pseudomonas alcaligenes infection and mortality in cultured Chinese sturgeon, Acipenser sinensis. Aquaculture 446: 37-41.

Yang G, Cao H, Jiang W, Hu B, Jian S, Wen C, et al. 2019. Dietary supplementation of Bacillus cereus as probiotics in Pengze crucian carp (Carassius auratus var. Pengze): Effects on growth performance, fillet quality, serum biochemical parameters and intestinal histology. Aquacult Res 50: 2207-2217.

Yukgehnaish K, Kumar P, Sivachandran P, Marimuthu K, Arshad A, Paray BA, Arockiaraj J. 2020. Gut microbiota metagenomics in aquaculture: factors influencing gut microbiome and its physiological role in fish. Rev Aquacult. DOI: 10.1111/raq.12416.

Zhang YJ, Zhang XY, Zhao HL Zhou MY, Li HJ, Gao ZM, et al. 2012. Idiomarina maris sp. nov., a marine bacterium isolated from sediment. Intl J Syst Evol Microbiol 62: 370-375.

Zhao Y, Yuan L, Wan J, Sun Z, Wang Y, Sun H. 2016. Effects of potential probiotic Bacillus cereus EN25 on growth, immunity and disease resistance of juvenile sea cucumber Apostichopus japonicus. Fish Shellfish Immunol 49: 237-242.

Zhong ZP, Liu Y, Liu HC, Wang F, Song L. et al. 2014. Idiomarina planktonica sp. nov., isolated from a saline lake. Intl J Syst Evol Microbiol 64: 3411-3416.

Zhu F, Wang Z, Sun BZ. 2016. Differential expression of microRNAs in shrimp Marsupenaeus japonicus in response to Vibrio alginolyticus infection. Dev Comp Immunol 55: 76-79. 